\title{
Botulism outbreaks in natural environments - an update
}

\author{
Mari Espelund ${ }^{1 *+}$ and Dag Klaveness ${ }^{2+}$ \\ ${ }^{1}$ Protection and Societal Security Division, Norwegian Defence Research Establishment, Kjeller, Norway \\ 2 Department of Biological Sciences, University of Oslo, Oslo, Norway
}

\section{Edited by:}

Steve J. Charette, Université Laval, Canada

\section{Reviewed by:}

Marie Archambault, University of Montreal, Canada

John W. Austin, Bureau of Microbial Hazards - Health Canada, Canada

\section{*Correspondence:}

Mari Espelund, Protection and Societal Security Division, Norwegian Defence Research Establishment, P.O. Box 25, N-2027 Kjeller, Norway e-mail: mari.espelund@ffi.no

${ }^{\dagger}$ Mari Espelund and Dag Klaveness have contributed equally to this work.
Clostridium botulinum comprises a diverse group of botulinum toxin-producing anaerobic rod-shaped spore-forming bacteria that are ubiquitously distributed in soils and aquatic sediments. Decomposition of plants, algae, and animals creates anaerobic environments that facilitate growth of $C$. botulinum, which may then enter into food webs leading to intoxication of animals. Via saprophytic utilization of nutrients, the bacteria rapidly sporulate, creating a reservoir of highly robust spores. In the present review, we focus on the occurrence of $C$. botulinum in non-clinical environments, and examine factors influencing growth and environmental factors associated with botulism outbreaks. We also outline cases involving specific environments and their biota. In wetlands, it has been found that some $C$. botulinum strains can associate with toxin-unaffected organisms-including algae, plants, and invertebrates-in which the bacteria appear to germinate and stay in the vegetative form for longer periods of time. We suggest the need for future investigations to resolve issues related to the environments in which $C$. botulinum spores may accumulate and germinate, and where the vegetative forms may multiply.

Keywords: Clostridium botulinum, botulism, serotype, spore, anaerobe, lakes, wetlands, soil

\section{INTRODUCTION}

The species Clostridium botulinum comprises multiple highly heterogeneous strains of rod-shaped anaerobic spore-forming bacteria, which are categorized into four groups (Groups I-IV) based on genomic relatedness. All C. botulinum strains produce botulinum toxin, which paralyzes animals by inhibiting acetylcholine release from synaptic vesicles at neuromuscular junctions. This toxin is classified into eight serotypes designated A-H (Collins and East, 1998; Barash and Arnon, 2014), of which A, B, E, and $\mathrm{F}$ are shown toxic to humans. Botulinum toxin-producing bacteria are divided into six groups: C. botulinum Groups I-IV as well as some strains of $C$. baratii and C. butyricum (Peck, 2009). Group I includes the proteolytic C. botulinum strains that produce botulinum toxin serotypes A, B, and F. Group II comprises non-proteolytic strains that produce toxin serotypes $\mathrm{B}, \mathrm{E}$, and $\mathrm{F}$. The strains in Group III produce serotypes $\mathrm{C}$ and $\mathrm{D}$, or mosaic $\mathrm{C} / \mathrm{D}$ toxins. Group VI strains, referred to as C. argentinense (Suen etal., 1988), produce toxin serotype G. Among the other species, C. butyricum produces botulinum toxin serotype $\mathrm{E}$ and $\mathrm{C}$. baratii produces serotype $\mathrm{F}$ (Hill et al., 2009).

Botulinum toxin genes exhibit remarkably variable organization. They can be chromosomally localized or localized on plasmids or phages (serotypes C and D). Serotype B transcription can occur through both genome-encoded and plasmid-encoded toxin gene clusters (Franciosa et al., 2009). Genome comparisons have revealed evidence of toxin cluster evolution through horizontal gene transfer, site-specific insertion, and recombination, and genomic analysis has supported the historic group classifications (Hill and Smith, 2013; Stringer et al., 2013). Thus, the factors affecting pathogenicity are apparently subjected to a higher evolutionary rate than the core genomes, allowing for fast environmental adaptation of the pathogen.
The ecology and properties are similar enough among Groups I-IV that it remains meaningful to discuss C. botulinum in the environment as a single group. C. botulinum spores persist in soils and aquatic sediments for decades, and propagate by predatordependent disease transmission. Upon entering the food webs of animals, C. botulinum toxins may intoxicate and kill the animal, or infect and proliferate and kill the prey. Saprophytic utilization of the prey via enzymes, including proteases and chitinases, makes nutrients available for massive spore and toxin production. Neurotoxin gene expression and toxin complex formation reportedly occur in the late exponential growth phase and the early stationary phase (Bradshaw et al., 2004; Kouguchi et al., 2006; Artin et al., 2008; Cooksley et al., 2010), and toxin production and sporulation seem to be co-regulated (Cooksley et al., 2010).

It appears that contaminated soils and sediments are primary environments for spores and serve as an incubation area, from which the pathogens may be mobilized (Long and Tauscher, 2006). C. botulinum is detected in, or may be associated with, various organisms that are not affected by the toxins-such as algae, plants, and invertebrates (Quortrup and Holt, 1941; Duncan and Jensen, 1976; Bohnel, 2002). Fish are carriers of C. botulinum, but botulism outbreaks in fish populations may lead to death on a large scale (Yule et al., 2006; Hannett et al., 2011). Avian botulism caused by $C$. botulinum type $\mathrm{C}$, mosaic $\mathrm{C} / \mathrm{D}$, or $\mathrm{E}$ is a common cause of death among waterfowl (Skulberg and Holt, 1987; Friend, 2002; Takeda et al., 2005; Lafrancois et al., 2011; Vidal et al., 2013). Unpredictable outbreaks with variable losses have been reported worldwide (Friend, 2002; Babinszky et al., 2008; Shin et al., 2010; Vidal et al., 2013). In recent years, large outbreaks in the Great Lakes, with high mortalities among fish and birds, have been well documented and analyzed (Perez-Fuentetaja et al., 2006, 2011; Lafrancois et al., 2011; Chun et al., 2013). In this review, we discuss factors related to botulism outbreaks in natural environments. 


\section{ENVIRONMENTS AND REGIONS}

Clostridium botulinum is ubiquitously present in the environment in soils, dust, and the marine and freshwater sediments of wetlands, rivers, and lakes. Spores in soil may be mobilized by surface waters in heavy rain, or dust carried away by wind (Long and Tauscher, 2006). Botulism has been characterized as a particularly substantial risk to humans in northern climatic regions, due to intoxication from poorly preserved food (Dolman, 1960; Hauschild and Gauvreau, 1985; Austin and Leclair, 2011; Fagan et al., 2011; Leclair et al., 2013b). Serotype E is dominant in sediments of the arctic and subarctic regions, whereas serotype B is most prevalent in soil (Johannsen, 1963; Miller, 1975; Huss, 1980; Hielm et al., 1998; Leclair et al., 2013a). The temperate climate zone of Europe shows the same distribution pattern, in which serotype $B$ is most prevalent in soil and serotype $\mathrm{E}$ is found in sediments (Huss, 1980), although serotypes C and D are also commonly found (Woudstra et al., 2012). In the temperate zone of Northern America, serotype A is most common west of the Mississippi river, and serotype $\mathrm{B}$ east of the Mississippi river (Shapiro et al., 1998), whereas serotype E is most common in the areas of the Great Lakes and the Pacific Northwest. In China, serotypes A-F have all been detected in the soil (Yamakawa et al., 1988; Gao et al., 1990; Fu and Wang, 2008). In Japan, the presence of botulinum toxin serotypes B, C, and E has been documented (Yamakawa et al., 1988; Yamakawa and Nakamura, 1992; Umeda et al., 2013). In general, environmental botulism outbreaks have been connected to serotypes $\mathrm{C}$, mosaic $\mathrm{C} / \mathrm{D}$, and $\mathrm{E}$.

Less documentation is available regarding botulism outbreaks in natural environments within subtropical and tropical climate zones. On the African continent, C. botulinum has been detected in the soils of Zambia and Kenya, with identification of serotypes A-D (Nightingale and Ayim, 1980; Yamakawa et al., 1990; Karasawa et al., 2000). In Australia, the serotypes A, B, and $\mathrm{D}$ have been detected, either identified from cases of botulism or in soil (Eales and Turner, 1952; Murrell and Stewart, 1983; Koepke et al., 2008). In the tropical region of Indonesian waters, botulinum toxin serotypes A, B, C, D, and F were detected, but not serotype E (Suhadi et al., 1981). In the tropical Indian subcontinent, $\mathrm{C}$ and $\mathrm{D}$ are the predominant serotypes found in fish and aquatic environments (Lalitha and Gopakumar, 2000), and serotype $\mathrm{E}$ has not been detected (Lalitha and Surendran, 2002).

In the field of food safety research, laboratory studies have investigated spore resistance and factors favoring and limiting C. botulinum germination and growth-for example, the tolerated ranges for temperature, $\mathrm{pH}$, and salinity (Chea et al., 2000; Hinderink et al., 2009; Derman et al., 2011; Stringer et al., 2011). However, the mechanisms triggering a botulism outbreak in the environment remain poorly understood. Several large-scale factors, such as lower water levels and/or higher summer surface water temperatures, have been correlated with larger outbreaks (Rocke et al., 1999; Perez-Fuentetaja et al., 2006, 2011; Lafrancois et al., 2011). Higher environmental botulism prevalences have also been reported when the sediment has a high organic matter content, the water has a $\mathrm{pH}$ of between 7.5 and 9.0, there is an overall negative redox potential, and the water temperature is above $20^{\circ} \mathrm{C}$ (Rocke and Samuel, 1999).

Pollution supports mass production of algae, followed by decay when packed ashore. In Lake Saint-Pierre, St. Lawrence River in Canada, years with low water levels coincided with eutrophic conditions and higher prevalence of filamentous green algae (Chlorophyceae), especially Cladophora (Cattaneo et al., 2013). Floating algae can create spots of strict anoxic conditions (Quortrup and Holt, 1941). In larger clearwater oligotrophic lakes in temperate climates, wind can cause circulation of surface water to a depth of 6-12 $\mathrm{m}$ or more. In the summer, this can expose the sediment surfaces within this depth range to temperatures of $10-20^{\circ} \mathrm{C}$ at an acceptable $\mathrm{pH}$ range for bacterial growth. Pollution of the nearshore waters can lead to developments as described for the great American lakes, in which massive shore accumulations of Cladophora served as biotic incubators for C. botulinum (Chun et al., 2013). Taken together, this observation indicate co-occurence between low water levels, growth of filamentous algae, and an increased risk of botulism.

A large number of samples from coastal waters and lakes have been investigated for the presence of C. botulinum strains or their spores. Many of these early studies were of importance for detection but provide superficial characterization of the localities sampled (Johannsen, 1963; Smith et al., 1978). Holomictic lakes in temperate regions may have two annual periods of circulation: immediately after ice-break and during the cooling period in autumn. A meso- to eutrophic lake may exhibit stagnation of the bottom water at a temperature near $4^{\circ} \mathrm{C}$, with complete oxygen deficit during the late summer and late winter seasons. During seasonal circulations, this oxygen-deficient water is mixed in with the rest of the lake. In temperate regions where ice is uncommon, the lakes may be mixing and fully aerated through the coldest season. Brown-water forest/bog lakes and meromictic lakes (with permanent anoxic water at the bottom) may accumulate sinking organic particulates, crustacean exuvia, dead fish, etc. Although decomposition may be delayed by $\mathrm{pH}$ and/or low temperature, such lakes should be of interest as reservoirs of anaerobic bacteria. It is possible that some degree of vertical transport, upwards from suboxic or anoxic levels, may be mediated by resistant zooplankton with diurnal migrations, e.g., larvae of Chaoborus and some Daphnia. Overall, the yearly cycles of lakes may be relevant with regards to conservation and distribution of spores and substrates (Wetzel, 2001).

Extensive reed beds are found in shallow lakes in temperate climates, like Lake Balaton in Hungary and Lake Neusiedler See in Austria. Wildlife botulism has rarely been recorded from within the reeds. However, bird botulism has been reported in ponds on the shores of Neusiedler See (Zechmeister et al., 2005). In Spain, inland wetlands are more often troubled by bird botulism (Vidal et al., 2013) than coastal wetlands with a tidal regime (Contreras de Vera et al., 1991). This is probably due to both the water movement and the salt concentration. C. botulinum serotype $\mathrm{C}$ was less prevalent in seasonally flooded marshes than in permanently flooded marshes (Sandler et al., 1993). Furthermore, higher salinity has a negative effect on C. botulinum growth (Segner etal., 1971; Webb etal., 2007), decreasing the risk of botulism outbreaks. 


\section{BIOTA AS RESERVOIRS AND VECTORS}

Clostridium botulinum spores released into the environment are robust, potentially persisting in soils and sediments for decades (Long and Tauscher, 2006). The bacterium has been found in the intestinal tract of healthy fish, birds, and mammals. C. botulinum serotype E does not multiply in the fish gut (Bott et al., 1968), and fish fed 500,000 spores per day (in pellets) did not acquire botulism (Eklund et al., 1984). Thus, the initial proliferation of bacterial germination and vegetative growth must occur somewhere in the environment. Once established, a botulism outbreak is self-perpetuating. During an avian botulism outbreak, the disease spreads through necrophagous flies depositing eggs on dead and toxic animal carcasses. The resulting maggots feed on the carcasses and concentrate the botulinum toxin. When other animals ingest the toxic maggots, they become the next victims (the carcass-maggot cycle). During outbreaks in fish, decomposing invertebrates and decaying fish sink to the lake bottom and are consumed by scavenging fish in an amplifying cycle. A study of channel catfish showed that their lethal dose of botulinum toxin $\mathrm{E}$ was less than the median lethal dose for mice (Chatla et al., 2012). Toxin levels may persist and remain lethal over the winter in larvae (Hubalék and Halouzka, 1991). A wide variety of organisms—such as algae, plants, and invertebrates-have been shown to contain botulinum toxin or C. botulinum DNA (Table 1). These organisms represent a biotic reservoir for $C$. botulinum, and may themselves become toxic upon anaerobic decomposition (Quortrup and Holt, 1941; Heckman, 1986).

For most of the insects listed, it is their submerged instars (e.g., mayflies) or larvae on carcasses (e.g., flies) that are vectors, with the important exception of the Coleoptera (beetles) and possibly the Corixidae (water boatmen).

It is clear that these organisms are involved in botulism outbreaks as part of the food web, and that birds and fish consume toxic decaying organic matter or toxic invertebrates, but little is known about the primary substrate in botulism outbreaks. Animals that die for other reasons but that contain spores in their digestive tract can serve as a substrate for bacterial germination. In the Great Lakes, invasive dreissenid mussels (Dreissena polymorpha and Dreissena rostriformis bugensis) and round gobies (Neogobius melanostomus; a benthic fish) have been suggested to contribute to the increased number of outbreaks by increasing the amount of decaying biomass (Getchell and Bowen, 2006). However, numerous other benthic organisms could potentially be responsible for transmitting C. botulinum to vertebrate prey organisms (PerezFuentetaja et al., 2011). During a disease outbreak in the Salton sea, PCR was used to test fish for serotype C-producing C. botulinum, but no difference in numbers of positives was detected among the groups of healthy, sick, and dead fish (Nol et al., 2004).

The filamentous green macroalgae Cladophora glomerata is reportedly associated with $C$. botulinum type E in Lake Michigan and Lake Ontario (Byappanahalli and Whitman, 2009; Chun et al., 2013). C. glomerata is globally widespread and can produce dense populations, especially under eutrophic conditions. Their high surface area is covered with organic compounds, which may form an ecological niche to diverse microbiota (Zulkifly et al., 2012). In floating algal mats, C. botulinum type $\mathrm{E}$ was found in high amounts of up to 15,000 cells (most probable number) per gram of dried algae (Chun et al., 2013). Heat treatment of Cladophora mat samples indicated the presence of C. botulinum vegetative cells (Chun et al., 2013). Another study analyzed senescent Cladophora samples from Lake Erie, and did not detect C. botulinum type E (Perez-Fuentetaja et al., 2011). An extensive survey revealed rich epiphytic microbiota on Cladophora thalli, but did not identify pathogenic bacteria, such as C. botulinum, associated with the alga and its epibionts (Zulkifly et al., 2012). The algae tested in this case were sampled from the attached macroalgae and not from floating decaying mats. In a laboratory experiment, sterilized plants and algae of different species, including Cladophora, were found

Table 1 | Clostridium botulinum and possible vector organisms.

\begin{tabular}{|c|c|c|c|c|c|}
\hline Environment & Vectors & Taxonomy & Sero-type & Area & Reference \\
\hline Freshwater & Plants & Ceratophyllum & C & Norway (Oslo) & Skulberg and Holt (1987) \\
\hline Freshwater & Plants & Phragmites Schoenoplectus & n.d. & Germany (Elbe estuary) & Heckman (1986) \\
\hline Freshwater & Invertebrates & $\begin{array}{l}\text { Gammarus (Crustacea), Oligochaeta } \\
\text { (Annelida), Chironomidae (Insectae), } \\
\text { Ephemeroptera (Insectae), Dreissenidae } \\
\text { (Mollusca) }\end{array}$ & $E$ & USA (Great Lakes) & $\begin{array}{l}\text { Perez-Fuentetaja etal. (2006, } \\
\text { 2011) }\end{array}$ \\
\hline Freshwater & $\begin{array}{l}\text { Algae, } \\
\text { invertebrates }\end{array}$ & Cladophora (Chlorophyceae) & $E$ & USA (Great Lakes) & $\begin{array}{l}\text { Byappanahalli and Whitman } \\
\text { (2009), Chun etal. (2013) }\end{array}$ \\
\hline Wetlands & Invertebrates & $\begin{array}{l}\text { Calliophoridae (Insectae), Ptychopteridae } \\
\text { (Insectae), Hirudineae (Annelida), Isopoda } \\
\text { (Crustacea) }\end{array}$ & $\mathrm{C}$ & $\begin{array}{l}\text { Czech Republic } \\
\text { (Moravia) }\end{array}$ & Hubalék and Halouzka (1991) \\
\hline Wetlands & Invertebrates & $\begin{array}{l}\text { Chironomidae (Insectae), Corixidae (Insectae), } \\
\text { Sarcophagidae (Insectae), Calliophoridae } \\
\text { (Insectae) }\end{array}$ & $C / D$ & Spain (central Spain) & Vidal et al. (2013) \\
\hline Wetlands & Invertebrates & Calliophoridae (Insectae), Coleoptera (Insectae) & $\mathrm{C}$ & USA (Utah) & Duncan and Jensen (1976) \\
\hline
\end{tabular}


to support anaerobe growth and toxin production of inoculated C. botulinum (Quortrup and Holt, 1941). The role of plants and algae as primary substrate for C. botulinum in wetland ecosystems must be further elucidated. Figure 1 presents a schematic view of $C$. botulinum in a freshwater environment. It has been speculated that botulism outbreaks may be triggered by animals dying of other reasons than C. botulinum infection. Spores will germinate in the dead body, and after toxin production the carcass in the next turn is food for maggots and other invertebrates and an outbreak cycle starts. It remains to investigate/show if algal- and plant-associated toxin can start a botulism outbreak.

\section{CONDITIONS PREVENTING BOTULISM OUTBREAKS}

Under natural conditions, there are a number of factors that can prevent C. botulinum growth. One limiting factor is the strong competition or even inhibiting effect by other bacteria (Smith, 1975; Girardin et al., 2002). Studies of marshland sediments have demonstrated inhibition of $C$. botulinum type $C$ by other bacteria, including Bacillus licheniformis, Bacillus mycoides/cereus, Streptococcus spp., and Clostridium spp. (Smith, 1975; Sandler et al., 1998). Additionally, degradation of preformed botulinum toxin by aerobic bacteria has been experimentally demonstrated (Quortrup and Holt, 1941). In some environments, salt is a growth-inhibiting factor. Growth can also be reduced by lower temperature and
pH, and acidification by fermentation (Quortrup and Holt, 1941). Fermentative processes of plant material in water by facultative anaerobic lactic acid bacteria (e.g., Leuconostoc) may initially create $\mathrm{CO}_{2}$, acetic acid and alcohol. However, as succession proceeds, the homofermentative species (Lactobacillus s. str.) take over and produce lactic acid, tolerating a lower $\mathrm{pH}$ (Buchanan and Gibbons, 1974; Giraffa et al., 2010).

One control measure that has been proposed to prevent outbreaks is to remove oxygen-deficient environments by raking the floating algae (Quortrup and Holt, 1941). Attempts have also been made to reduce the magnitude of botulism outbreaks by collecting carcasses, which appears to enhance survival compared to in areas with a higher carcass density (Evelsizer et al., 2010). It has been suggested that a functional ecosystems can better resist disease outbreak than dysfunctional ecosystems (Riley et al., 2008). An interesting research focus will be to further elucidate the mechanisms by which Clostridia are excluded, prevented, or outcompeted in many complex bacterial communities, in spite of favorable physical conditions, such as $\mathrm{pH}$, salinity, and anoxia.

\section{C. botulinum AND CLIMATE CHANGE}

An important question to discuss is whether climate change has or will contribute to increasing outbreaks of botulism. A study of the Salton Sea from 1907 to 1999 showed that avian diseases

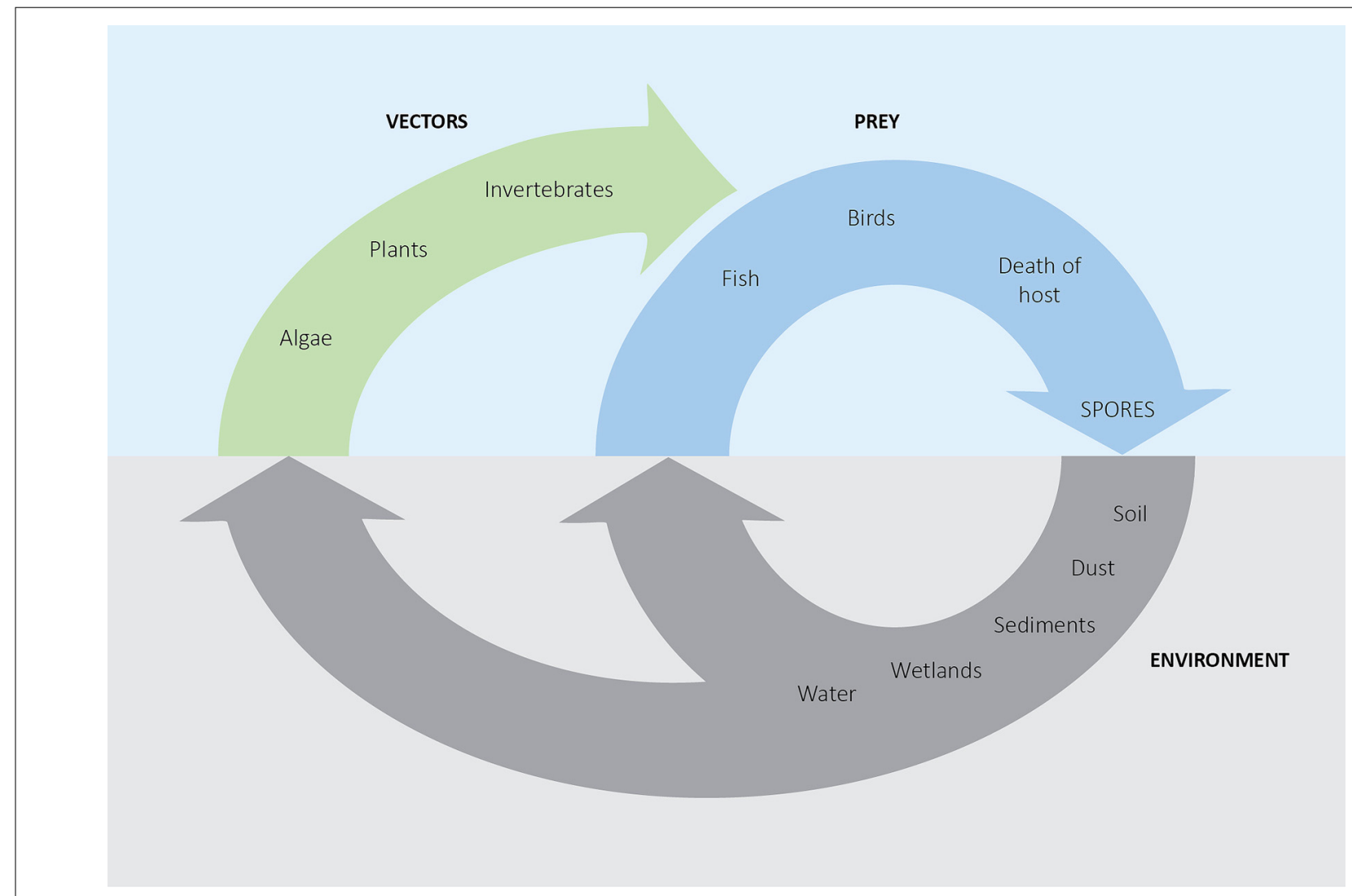

FIGURE 1 | Schematic representation of the role of $\boldsymbol{C}$. botulinum in a freshwater ecosystem. Resistant spores are released from dead hosts into the abiotic environment, and are spread by air and waterways. The spores may directly infect prey hosts or can be taken up by toxin-unaffected organisms, forming a biotic reservoir. 
caused by various agents increased over the course of the 1990s (Friend, 2002). A study of Lake Michigan from 1963 to 2008 found a cyclic occurrence of outbreaks, with no increased frequency of outbreaks during the study period (Lafrancois et al., 2011). Since 1998, there have been yearly botulism outbreaks in Lake Erie, which have been spreading to other deeper Great Lakes (PerezFuentetaja et al., 2011). During dry periods, lower lake levels and high summer temperatures increase the growth of the filamentous green macroalgae Cladophora (Zulkifly et al., 2012), along with the risk of botulism outbreaks (Lafrancois et al., 2011). In the wetlands of central Spain, drought induced by overexploitation of groundwater resources represents an increased risk factor for local botulism outbreaks (Vidal et al., 2013). As climate forecasts predict warmer and wetter weather, in addition to more weather extremes, one may expect more outbreaks due to the warmer climate, especially if combined with prolonged dry periods and polluted water supporting blooms of benthic algae.

\section{ACKNOWLEDGMENTS}

The work was supported by Norwegian Defence Research Establishment (FFI) and the University of Oslo. We thank Jaran Strand Olsen and Janet Blatny for critically reading the manuscript.

\section{REFERENCES}

Artin, I., Carter, A. T., Holst, E., Lovenklev, M., Mason, D. R., Peck, M. W., et al. (2008). Effects of carbon dioxide on neurotoxin gene expression in nonproteolytic Clostridium botulinum type E. Appl. Environ. Microbiol. 74, 2391-2397. doi: 10.1128/AEM.02587-07

Austin, J. W., and Leclair, D. (2011). Botulism in the North: a disease without borders. Clin. Infect. Dis. 52, 593-594. doi: 10.1093/cid/ciq256

Babinszky, G., Csitari, G., and Jozsa, S. (2008). Observations on environmental factors in connection with avian botulism outbreaks in a Hungarian wetland habitat. Acta Microbiol. Immunol. Hung. 55, 455-464. doi: 10.1556/AMicr.55.2008.4.10

Barash, J. R., and Arnon, S. S. (2014). A novel strain of Clostridium botulinum that produces type B and type H botulinum toxins. J. Infect. Dis. 209, 183-191. doi: 10.1093/infdis/jit449

Bohnel, H. (2002). Household biowaste containers (bio-bins) - potential incubators for Clostridium botulinum and botulinum neurotoxins. Water Air Soil Pollut. 140, 335-341. doi: 10.1023/A:1020169520369

Bott, T. L., Johnson, J., Foster, E. M., and Sugiyama, H. (1968). Possible origin of high incidence of Clostridium botulinum type $\mathrm{E}$ in an inland bay (Green Bay of Lake Michigan). J. Bacteriol. 95, 1542-1547.

Bradshaw, M., Dineen, S. S., Maks, N. D., and Johnson, E. A. (2004). Regulation of neurotoxin complex expression in Clostridium botulinum strains 62A, Hall A-hyper, and NCTC 2916. Anaerobe 10, 321-333. doi: 10.1016/j.anaerobe.2004.07.001

Buchanan, R. E., and Gibbons, N. E. (1974). Bergey's Manual of Determinative Bacteriology, 8th Edn. Baltimore: Williams \& Wilkins.

Byappanahalli, M. N., and Whitman, R. L. (2009). Clostridium botulinum type E occurs and grows in the alga Cladophora glomerata. Can. J. Fish. Aquat. Sci. 66, 879-882. doi: 10.1139/F09-052

Cattaneo, A., Hudon, C., Vis, C., and Gagnon, P. (2013). Hydrological control of filamentous green algae in a large fluvial lake (Lake Saint-Pierre, St. Lawrence River, Canada). J. Great Lakes Res. 39, 409-419. doi: 10.1016/j.jglr.2013. 06.005

Chatla, K., Gaunt, P. S., Hanson, L., Gao, D. X., and Wills, R. (2012). Determination of the median lethal dose of botulinum serotype $\mathrm{E}$ in channel catfish fingerlings. J. Aquat. Anim. Health 24, 105-109. doi: 10.1080/08997659.2012. 675935

Chea, F. P., Chen, Y. H., Montville, T. J., and Schaffner, D. W. (2000). Modeling the germination kinetics of Clostridium botulinum 56A spores as affected by temperature, pH, and sodium chloride. J. Food Prot. 63, 1071-1079.

Chun, C. L., Ochsner, U., Byappanahalli, M. N., Whitman, R. L., Tepp, W. H., Lin, G. Y., et al. (2013). Association of toxin-producing Clostridium botulinum with the macroalga cladophora in the Great Lakes. Environ. Sci. Technol. 47, 2587-2594. doi: $10.1021 /$ es304743m

Collins, M. D., and East, A. K. (1998). Phylogeny and taxonomy of the food-borne pathogen Clostridium botulinum and its neurotoxins. J. Appl. Microbiol. 84, 5-17. doi: 10.1046/j.1365-2672.1997.00313.x

Contreras de Vera, A., Garcia Fernandez, A., Cubero Pablo, M. J., and Leon-Vizcaino, L. (1991). Low prevalence of C. botulinum in Spanish wetlands with a tidal regime. Vet. Rec. 128, 187-188. doi: 10.1136/vr.128.8.187

Cooksley, C. M., Davis, I. J., Winzer, K., Chan, W. C., Peck, M. W., and Minton, N. P. (2010). Regulation of neurotoxin production and sporulation by a putative agrBD signaling system in proteolytic Clostridium botulinum. Appl. Environ. Microbiol. 76, 4448-4460. doi: 10.1128/AEM.03038-09

Derman, Y., Lindstrom, M., Selby, K., and Korkeala, H. (2011). Growth of group II Clostridium botulinum strains at extreme temperatures. J. Food Prot. 74, 17971804. doi: 10.4315/0362-028X.JFP-11-187

Dolman, C. E. (1960). Type E botulism: a hazard of the north. Arctic 13, 230. doi: 10.14430/arctic3704

Duncan, R. M., and Jensen, W. L. (1976). A relationship between avian carcasses and living invertebrates in the epizootiology of avian botulism. J. Wildl. Dis. 12, 116-126. doi: 10.7589/0090-3558-12.1.116

Eales, C. E., and Turner, A.W. (1952). Description of Clostridium botulinum type-D recovered from soil in South Australia. Austr. J. Exp. Biol. Med. Sci. 30, 295-300. doi: 10.1038/icb.1952.27

Eklund, M. W., Poysky, F. T., Peterson, M. E., Peck, L. W., and Brunson, W. D. (1984). Type-E botulism in Salmonids and conditions contributing to outbreaks. Aquaculture 41, 293-309. doi: 10.1016/0044-8486(84)90198-4

Evelsizer, D. D., Clark, R. G., and Bollinger, T. K. (2010). Relationships between local carcass density and risk of mortality in molting mallards during avian botulism outbreaks. J. Wildl. Dis. 46, 507-513. doi: 10.7589/0090-3558-46.2.507

Fagan, R. P., McLaughlin, J. B., Castrodale, L. J., Gessner, B. D., Jenkerson, S. A., Funk, E. A., et al. (2011). Endemic foodborne botulism among Alaska Native persons-Alaska, 1947-2007. Clin. Infect. Dis. 52, 585-592. doi: 10.1093/cid/ ciq240

Franciosa, G., Maugliani, A., Scalfaro, C., and Aureli, P. (2009). Evidence that plasmid-borne botulinum neurotoxin type B genes are widespread among Clostridium botulinum serotype B strains. PLoS ONE 4:e4829. doi: 10.1371/journal.pone.0004829

Friend, M. (2002). Avian disease at the Salton Sea. Hydrobiologia 473, 293-306. doi: 10.1023/A: 1016570810004

Fu, S.-W., and Wang, C.-H. (2008). An overview of type E botulism in China. Biomed. Environ. Sci. 21, 353-356. doi: 10.1016/S0895-3988(08)60054-9

Gao, Q. Y., Huang, Y. F., Wu, J. G., Liu, H. D., and Xia, H. Q. (1990). A review of botulism in China. Biomed. Environ. Sci. 3, 326-336.

Getchell, R. G., and Bowen, P. R. (2006). Ecology of type E botulism within dreissenid mussel beds. Aquat. Invaders 17, 1-8.

Giraffa, G., Chanishvili, N., and Widyastuti, Y. (2010). Importance of lactobacilli in food and feed biotechnology. Res. Microbiol. 161, 480-487. doi: 10.1016/j.resmic.2010.03.001

Girardin, H., Albagnac, C., Dargaignaratz, C., Nguyen-The, C., and Carlin, F. T. (2002). Antimicrobial activity of foodborne Paenibacillus and Bacillus spp. against Clostridium botulinum. J. Food Prot. 65, 806-813.

Hannett, G. E., Stone, W. B., Davis, S. W., and Wroblewski, D. (2011). Biodiversity of Clostridium botulinum type E associated with a large outbreak of botulism in wildlife from Lake Erie and Lake Ontario. Appl. Environ. Microbiol. 77, 10611068. doi: 10.1128/AEM.01578-10

Hauschild, A. H. W., and Gauvreau, L. (1985). Foodborne botulism in Canada, 1971-84. Can. Med. Assoc. J. 133, 1141-1146.

Heckman, C. W. (1986). The role of marsh plants in the transport of nutrient as shown by a quantitative model for the freshwater section of the Elbe estuary. Aquat. Bot. 25, 139-151. doi: 10.1016/0304-3770(86)90050-1

Hielm, S., Hyytia, E., Andersin, A. B., and Korkeala, H. (1998). A high prevalence of Clostridium botulinum type E in Finnish freshwater and Baltic Sea sediment samples. J. Appl. Microbiol. 84, 133-137. doi: 10.1046/j.1365-2672.1997.00331.x

Hill, K. K., and Smith, T. J. (2013). Genetic diversity within Clostridium botulinum serotypes, botulinum neurotoxin gene clusters and toxin subtypes. Curr. Top. Microbiol. Immunol. 364, 1-20. doi: 10.1007/978-3-642-33570-9_1

Hill, K. K., Xie, G., Foley, B. T., Smith, T. J., Munk, A. C., Bruce, D., et al. (2009). Recombination and insertion events involving the botulinum neurotoxin complex genes in Clostridium botulinum types $\mathrm{A}, \mathrm{B}, \mathrm{E}$ and $\mathrm{F}$ and 
Clostridium butyricum type E strains. BMC Biol. 7:66. doi: 10.1186/1741-70077-66

Hinderink, K., Lindstrom, M., and Korkeala, H. (2009). Group I Clostridium botulinum strains show significant variation in growth at low and high temperatures. J. Food Prot. 72, 375-383. doi: 10.4315/0362-028X.JFP11-187

Hubalék, Z., and Halouzka, J. (1991). Persistence of Clostridium botulinum type-C in blow fly (Calliphoridae) larvae as a possible cause of avian botulism in spring. J. Wildl. Dis. 27, 1, 81-85. doi: 10.7589/0090-3558-27.1.81

Huss, H. H. (1980). Distribution of Clostridium botulinum. Appl. Environ. Microbiol. 39, 764-769.

Johannsen, A. (1963). Clostridium botulinum in Sweden and adjacent waters. J. Appl. Bacteriol. 26, 43-47. doi: 10.1111/j.1365-2672.1963.tb01153.x

Karasawa, T., Wang, X., Maegawa, T., Nakamura, S., Hang'ombe, B. M., and Isogai, E. (2000). Demonstration of botulinum toxins of types B and D in soil samples from Zambia. Ann. Trop. Med. Parasitol. 94, 409-411.

Koepke, R., Sobel, J., and Arnon, S. S. (2008). Global occurrence of infant botulism 1976-2006. Pediatrics 122, e73-e82. doi: 10.1542/peds.2007-1827

Kouguchi, H., Suzuki, T., Hasegawa, K., Mutoh, S., Watanabe, T., Niwa, K., et al (2006). Quantitative detection of gene expression and toxin complex produced by Clostridium botulinum serotype D strain 4947. J. Microbiol. Methods 67, 416-423. doi: 10.1016/j.mimet.2006.04.013

Lafrancois, B. M., Riley, S. C., Blehert, D. S., and Ballmann, A. E. (2011). Links between type E botulism outbreaks, lake levels, and surface water temperatures in Lake Michigan, 1963-2008. J. Great Lakes Res. 37, 86-91. doi: 10.1016/j.jglr.2010.10.003

Lalitha, K. V., and Gopakumar, K. (2000). Distribution and ecology of Clostridium botulinum in fish and aquatic environments of a tropical region. Food Microbiol. 17, 535-541. doi: 10.1006/fmic.2000.0346

Lalitha, K. V., and Surendran, P. K. (2002). Occurrence of Clostridium botulinum in fresh and cured fish in retail trade in Cochin (India). Int. J. Food Microbiol. 72, 169-174. doi: 10.1016/S0168-1605(01)00632-8

Leclair, D., Farber, J. M., Doidge, B., Blanchfield, B., Suppa, S., Pagotto, F., et al. (2013a). Distribution of Clostridium botulinum type E strains in Nunavik, Northern Quebec, Canada. Appl. Environ. Microbiol. 79, 646-654. doi: 10.1128/AEM.05999-11

Leclair, D., Fung, J., Isaac-Renton, J. L., Proulx, J. F., May-Hadford, J., Ellis, A., et al. (2013b). Foodborne botulism in Canada, 1985-2005. Emerg. Infect. Dis. 19, 961-968. doi: 10.3201/eid1906.120873

Long, S. C., and Tauscher, T. (2006). Watershed issues associated with Clostridium botulinum: a literature review. J. Water Health 4, 277-288.

Miller, L. G. (1975). Observations on distribution and ecology of Clostridium botulinum type E in Alaska. Can. J. Microbiol. 21, 920-926. doi: 10.1139/m75-136

Murrell, W. G., and Stewart, B. J. (1983). Botulism in New South-Wales, 1980-1981. Med. J. Aust. 1, 13-17.

Nightingale, K. W., and Ayim, E. N. (1980). Outbreak of botulism in Kenya after ingestion of white ants. $\mathrm{Br}$. Med. J. 281, 1682-1683. doi: 10.1136/bmi.281.6256.1682-a

Nol, P., Rocke, T. E., Gross, K., and Yuill, T. M. (2004). Prevalence of neurotoxic Clostridium botulinum type $\mathrm{C}$ in the gastrointestinal tracts of tilapia (Oreochromis mossambicus) in the Salton Sea. J. Wildl. Dis. 40, 414-419. doi: 10.7589/00903558-40.3.414

Peck, M. W. (2009). Biology and genomic analysis of Clostridium botulinum. Adv. Microb. Physiol. 55, 183-265. doi: 10.1016/S0065-2911(09)05503-9

Perez-Fuentetaja, A., Clapsadl, M. D., Einhouse, D., Bowser, P. R., Getchell, R. G., and Lee, W. T. (2006). Influence of limnological conditions on Clostridium botulinum type E presence in eastern Lake Erie sediments (Great Lakes, USA). Hydrobiologia 563, 189-200. doi: 10.1007/s10750-005-0011-1

Perez-Fuentetaja, A., Clapsadl, M. D., Getchell, R. G., Bowser, P. R., and Lee, W. T. (2011). Clostridium botulinum type E in Lake Erie: Inter-annual differences and role of benthic invertebrates. J. Great Lakes Res. 37, 238-244. doi: 10.1016/j.jglr.2011.03.013

Quortrup, E. R., and Holt, A. L. (1941). Detection of potential botulinustoxin-producing areas in Western Duck Marshes with suggestions for control. J. Bacteriol. 41, 363-372.

Riley, S. C., Munkittrick, K. R., Evans, A. N., and Krueger, C. C. (2008). Understanding the ecology of disease in Great Lakes fish populations. Aquat. Ecosyst. Health Manag. 11, 321-334. doi: 10.1080/14634980802301638
Rocke, T. E., Euliss, N. H., and Samuel, M. D. (1999). Environmental characteristics associated with the occurrence of avian botulism in wetlands of a northern California refuge. J. Wildl. Manag. 63, 358-368. doi: 10.2307/ 3802520

Rocke, T. E., and Samuel, M. D. (1999). Water and sediment characteristics associated with avian botulism outbreaks in wetlands. J. Wildl. Manag. 63, 1249-1260. doi: $10.2307 / 3802842$

Sandler, R. J., Rocke, T. E., Samuel, M. D., and Yuill, T. M. (1993). Seasonal prevalence of Clostridium-botulinum type-C in sediments of a Northern California wetland. J. Wildl. Dis. 29, 533-539. doi: 10.7589/0090-3558-29.4.533

Sandler, R. J., Rocke, T. E., and Yuill, T. M. (1998). The inhibition of Clostridium botulinum type C by other bacteria in wetland sediments. J. Wildl. Dis. 34, 4, 830-833. doi: 10.7589/0090-3558-34.4.830

Segner, W. P., Schmidt, C. F., and Boltz, J. K. (1971). Enrichment, isolation, and cultural characteristics of marine strains of Clostridium botulinum type C. Appl. Microbiol. 22, 1017-1024.

Shapiro, R. L., Hatheway, C., and Swerdlow, D. L. (1998). Botulism in the United States: a clinical and epidemiologic review. Ann. Intern. Med. 129, 221-228. doi: 10.7326/0003-4819-129-3-199808010-00011

Shin, N. R., Byun, S. H., Chun, J. H., Shin, J. H., Kim, Y. J., Kim, J. H., et al. (2010). An outbreak of type C botulism in waterbirds: Incheon, Korea. J. Wildl. Dis. 46, 912-917. doi: 10.7589/0090-3558-46.3.912

Skulberg, A., and Holt, G. (1987). "Avian botulism in scandinavia," in Avian Botulism, an International Perspective, eds M. W. Eklund and V. R. Dowell, Jr. (Springfield, IL: Charles C Thomas), 107-110.

Smith, G. R., Milligan, R. A., and Moryson, C. J. (1978). Clostridium botulinum in aquatic environments in Great Britain and Ireland. J. Hyg. 80, 431-438. doi: 10.1017/S0022172400024906

Smith, L. D. (1975). Inhibition of Clostridium botulinum by strains of Clostridium perfringens isolated from soil. Appl. Microbiol. 30, 319-323.

Stringer, S. C., Carter, A. T., Webb, M. D., Wachnicka, E., Crossman, L. C., Sebaihia, M., et al. (2013). Genomic and physiological variability within group II (nonproteolytic) Clostridium botulinum. BMC Genomics 14:333. doi: 10.1186/14712164-14-333

Stringer, S. C., Webb, M. D., and Peck, M. W. (2011). Lag time variability in individual spores of Clostridium botulinum. Food Microbiol. 28, 228-235. doi: 10.1016/j.fm.2010.03.003

Suen, J. C., Hatheway, C. L., Steigerwalt, A. G., and Brenner, D. J. (1988). Clostridium argentinense sp. nov: a genetically homogeneous group composed of all strains of Clostridium botulinum toxin type $\mathrm{G}$ and some nontoxigenic strains previously identified as Clostridium subterminale or Clostridium hastiforme. Int. J. Syst. Bacteriol. 38, 375-381. doi: 10.1099/00207713-38-4-375

Suhadi, F., Thayib, S. S., and Sumarsono, N. (1981). Distribution of Clostridium botulinum around fishing areas of the western part of Indonesian waters. Appl. Environ. Microbiol. 41, 1468-1471.

Takeda, M., Tsukamoto, K., Kohda, T., Matsui, M., Mukamoto, M., and Kozaki, S. (2005). Characterization of the neurotoxin produced by isolates associated with avian botulism. Avian Dis. 49, 376-381. doi: 10.1637/7347022305R1.1

Umeda, K., Wada, T., Kohda, T., and Kozaki, S. (2013). Multi-locus variable number tandem repeat analysis for Clostridium botulinum type B isolates in Japan: comparison with other isolates and genotyping methods. Infect. Gen. Evol. 16, 298-304. doi: 10.1016/j.meegid.2013.02.022

Vidal, D., Anza, I., Taggart, M. A., Perez-Ramrez, E., Crespo, E., Hofle, U., et al. (2013). Environmental factors influencing the prevalence of a Clostridium botulinum type $\mathrm{C} / \mathrm{D}$ mosaic strain in nonpermanent Mediterranean wetlands. Appl. Environ. Microbiol. 79, 4264-4271. doi: 10.1128/AEM.01191-13

Webb, M. D., Pin, C., Peck, M. W., and Stringer, S. C. (2007). Historical and contemporary $\mathrm{NaCl}$ concentrations affect the duration and distribution of lag times from individual spores of nonproteolytic Clostridium botulinum. Appl. Environ. Microbiol. 73, 2118-2127. doi: 10.1128/AEM. 01744-06

Wetzel, R. G. (2001). Limnology. Lake and River Ecosystems, Third Edn. San Diego, CA: Academic Press.

Woudstra, C., Skarin, H., Anniballi, F., Fenicia, L., Bano, L., Drigo, I., et al. (2012). Neurotoxin gene profiling of Clostridium botulinum types $\mathrm{C}$ and D native to different countries within Europe. Appl. Environ. Microbiol. 78, 3120-3127. doi: 10.1128/AEM.07568-11 
Yamakawa, K., Kamiya, S., Nishida, S., Yoshimura, K., Yu, H., Lu, D. Y., et al. (1988). Distribution of Clostridium botulinum in Japan and in Shinkiang district of China. Microbiol. Immunol. 32, 579-587. doi: 10.1111/j.1348-0421.1988. tb01419.x

Yamakawa, K., Kamiya, S., Yoshimura, K., Nakamura, S., and Ezaki, T. (1990). Clostridium botulinum in the soil of Kenya. Ann. Trop. Med. Parasitol. 84, 201-203.

Yamakawa, K., and Nakamura, S. (1992). Prevalence of Clostridium botulinum type $\mathrm{E}$ and coexistence of C. botulinum nonproteolytic type B in the river soil of Japan. Microbiol. Immunol. 36, 583-591. doi: 10.1111/j.1348-0421.1992.tb02058.x

Yule, A. M., Barker, I. K., Austin, J. W., and Moccia, R. D. (2006). Toxicity of Clostridium botulinum type E neurotoxin to Great Lakes fish: implications for avian botulism. J. Wildl. Dis. 42, 479-493. doi: 10.7589/0090-3558-42.3.479

Zechmeister, T. C., Kirschner, A. K. T., Fuchsberger, M., Gruberl, S. G., Suss, B., Rosengarten, R., et al. (2005). Prevalence of botulinum neurotoxin C1 and its corresponding gene in environmental samples from low and high risk avian botulism areas. ALTEX 22, 185-195.

Zulkifly, S., Hanshew, A., Young, E. B., Lee, P., Graham, M. E., Graham, M. E., et al. (2012). The epiphytic microbiota of the globally widespread macroalga
Cladophora glomerata (Chlorophyta, Cladophorales). Am. J. Bot. 99, 1541-1552. doi: 10.3732/ajb.1200161

Conflict of Interest Statement: The authors declare that the research was conducted in the absence of any commercial or financial relationships that could be construed as a potential conflict of interest.

Received: 28 February 2014; accepted: 24 May 2014; published online: 11 June 2014. Citation: Espelund $M$ and Klaveness D (2014) Botulism outbreaks in natural environments - an update. Front. Microbiol. 5:287. doi: 10.3389/fmicb.2014.00287 This article was submitted to Microbial Physiology and Metabolism, a section of the journal Frontiers in Microbiology.

Copyright (C) 2014 Espelund and Klaveness. This is an open-access article distributed under the terms of the Creative Commons Attribution License (CC BY). The use, distribution or reproduction in other forums is permitted, provided the original author(s) or licensor are credited and that the original publication in this journal is cited, in accordance with accepted academic practice. No use, distribution or reproduction is permitted which does not comply with these terms. 